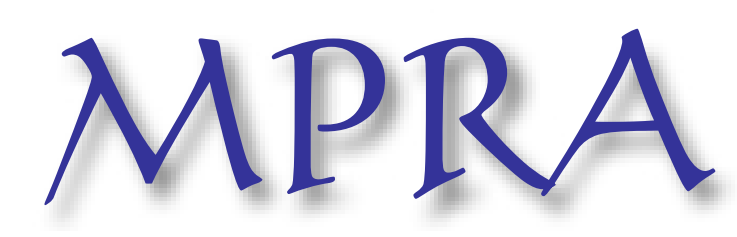

Munich Personal RePEc Archive

\title{
HUMAN RESOURCE POLICIES AND FIRM INNOVATION: THE MODERATING EFFECTS OF ECONOMIC AND INSTITUTIONAL CONTEXT
}

Krammer, Sorin

University of Exeter Business School

28 July 2021

Online at https://mpra.ub.uni-muenchen.de/109486/

MPRA Paper No. 109486, posted 30 Aug 2021 15:03 UTC 


\title{
HUMAN RESOURCE POLICIES AND FIRM INNOVATION: \\ THE MODERATING EFFECTS OF ECONOMIC AND INSTITUTIONAL CONTEXT
}

\author{
Prof. SORIN M.S. KRAMMER \\ University of Exeter Business School \\ Science, Technology, Innovation and Entrepreneurship (SITE) Department \\ Streatham Court, Rennes Drive \\ Exeter EX4 4PU, U.K. \\ E-mail: $\underline{\text { S.Krammer@exeter.ac.uk }}$ \\ Tel: +44 (0) 1392723244
}

\section{Acknowledgements}

The author would like to thank the Editor (Stelvia Matos), two anonymous reviewers, and the participants at the Academy of Management Online Meeting 2021 for very useful feedback on prior iterations of this work. I am grateful also to Fanni Gaal for some excellent research assistance in the early stages of this project. Emmanuella-Celine this one is for your first birthday. 


\title{
HUMAN RESOURCE POLICIES AND FIRM INNOVATION: \\ THE MODERATING EFFECTS OF ECONOMIC AND INSTITUTIONAL CONTEXT
}

\begin{abstract}
This paper examines the effects of human resource (HR) policies on firm innovation. Specifically, we argue that firms who implement policies to stimulate job autonomy and performance-based pay will be more likely to innovate, as proxied by investments in R\&D. In addition, we contend that the institutional (i.e., labour regulations) and competitive (i.e., pressure from imports) contexts in which a firm operates will affect the relationship between HR policies and innovation, albeit in different ways. We test these hypotheses using a dataset of more than 900 firms across a heterogenous set of 12 countries, majority of which are emerging markets. We find strong empirical backing for the role of both job autonomy and performance-based pay policies in stimulating firm innovation, and partial support for the moderating effects of institutional and competitive contexts of this relationship.
\end{abstract}

Keywords: Human Resource Management; Job autonomy; Performance-based pay; Firm innovation; Labour regulations; Import competition 


\section{INTRODUCTION}

Innovation performance rests on a firm's ability to create, maintain, protect and utilize knowledge (Cohen and Levinthal, 1990; Daneels, 2002; Inderts, 2009; Maksimov, Wang and Luo, 2017; Kafouros, Aliyev, and Krammer, 2021), and its success is often a reflection of the macro-external environment in which the firm operates (Von Zedtwitz and Gassmann, 2002; Aw, Roberts, and Xu, 2011; Heij et al., 2020). Among its many determinants, Human Resource (HR) management is particularly important for innovation (Lee and Kelley, 2008; Brenton and Levin, 2012) as human capital remains an indispensable ingredient in this process (O'Conner and McDermott, 2004; Loon, Otaye-Ebede, and Stewart; 2020). HR policies have the potential to create and sustain a suitable infrastructure for the development of the new products, technologies and organizational routines by stimulating employees to be creative, collaborative, independent and ambitious (Lau and Ngo, 2004; Shipton et al., 2006; Beugelsdijk, 2008). Yet, despite these innate opportunities, we still lack sufficient knowledge on how and when internal HR policies are able to successfully stimulate a firm's ability to innovate (Andreeva et al., 2017; Park et al., 2019).

To answer this question we examine the relationship between HR policies and innovation as well as several contingencies that can affect this relationship. To capture innovation we focus on one of the most frequently used indicators of innovation in the literature, namely investment in R\&D (Coombs and Bierly, 2006; Raymond and St-Pierre, 2010; Heij et al., 2020). While innovation is a collective result of creative efforts of individuals (Wang and Cheng, 2010; Sears and Baba, 2011), organizational policies put together the work environment in which employees' creativity can be both encouraged and stifled (Amabile, 1988). Positive internal prescriptions will facilitate a firm's generation and implementation of novel ideas (Beugelsdijk, 2008) as well as bridge any existing gaps between individual and organizational goals (Jensen and Meckling, 1976). 
In particular, we propose that firms with specific HR policies regarding promotion and merit-based pay (PBP) or job autonomy (JA) will be more likely to pursue innovation by investing in R\&D. Furthermore, we posit that the efficiency of these internal mechanisms to promote new product development and innovation will be conditioned by the economic and institutional characteristics of the environment in which a firm operates (Krammer, 2019). Specifically, we theorize that greater competitive pressures from foreign competitors as well as more rigid labour regulations will have a similar, yet assymetric effect on this relationship: they will weaken the efficiency of PBP policies while enhancing the effects of JA measures on firm innovation.

We test our hypotheses using data on more than 900 firms from ten transition economies from Central Asia and Eastern Europe, plus India and Germany. This mix of countries exhibits significant heterogeneity in terms of labour regulations (Botero et al. 2004), institutional quality (Meyer et al. 2009), and national innovative infrastructure (Krammer 2009) which allows us to put to the test the effects of HR policies across very different economic and institutional settings. Furthermore, only 40 percent of firms in this context perform formal R\&D suggesting that such commitments are salient indicators of their innovative performance, more so than new products which are widely reported by firms in less developed markets (Lederman, 2010; Goedhuys, 2007) ${ }^{1}$.

We make several contributions. First, we showcase the complex role of the external context in influencing the effectiveness of a firm's HR policies towards its innovative performance (Bamber et al., 2016; Glaister et al., 2018). While prior studies have examined the role of internal capabilities such as organizational culture (Lau and Ngo, 2004) or management skills (Park et al.,

\footnotetext{
${ }^{1}$ For instance, the average percentage fo firms introducing new products in Eastern Europe and Central Asia was 57\% while only $26 \%$ of firms invest in formal R\&D (Krammer, 2019, p.12). Similar large differences between these two proxies have been reported for African nations (Goedhuys, 2007) and more generally for developing versus developed nations (Lederman, 2010, p.618) confirming the idea that, particularly in the case of emerging markets, the propensity to invest in $R \& D$ remains a salient indicator of innovation.
} 
2019) we show that external factors, such as competition from imported products (Nocco, Ottaviano and Salto, 2019; Traiberman, 2019), interact differently with various HR policies in determining firm innovation. This finding supports recent calls in this area for further investigation of the interplay and contingencies of these complex relationships (Andreeva et al., 2019).

Second, we contribute to the institution-based view of the firm (Peng, Sun, Pinkham and Chen, 2009) by demonstrating the indirect effect of formal institutions, as captured by labour regulations, in moderating the relationship between HR practices and firm innovation. While extant studies have examined the direct role of institutions in determining firm performance (Hitt et al., 2000; Yasar, Paul, and Ward, 2011; Fuentelsaz, Garrido, and Maicas, 2020), our knowledge of the nature and magnitude of the indirect effects of institutions remains scant $(\mathrm{Lu}, \mathrm{Liu}$, Wright and Filatotchev, 2014; Krammer, 2015), and in particular towards explicating the external factors that enable or deter innovation performance (Krammer, 2019).

Finally, we highlight the importance of HR policies (i.e., job autonomy and pay/promotion incentives) for firm innovation in an international, comparative setting of 12 heterogeneous economies around the world, as opposed to previous studies in this area which have all been confined to single countries (e.g., Lau and Ngo, 2004; Beugelsdijk, 2008; Ceylan, 2013; Andreeva et al, 2017). In this way, we are able to provide more definitive and generalizable evidence on the direct role HR policies play in stimulating firm innovation and some of the salient macrocontingencies that affect this relationship, augmenting a large body of work on the drivers of innovation and potential policy responses (Von Zedtwitz and Gassmann, 2002; Krammer, 2009; Lopez-Berzosa and Gawer, 2014; Schot and Steinmueller, 2018).

\section{THEORY AND BACKGROUND}




\subsection{Creativity and firm innovation}

Innovation is a robust prerequisite for firm survival, growth and commercial success, and therefore finding out what makes certain firms more innovative than others is one of the key areas of research across multiple disciplines (Schumpeter, 1934; Cohen and Levinthal, 1990). Among the multitude of explanations proposed and vetted, organizational behavior scholars have paid special attention to creativity of employees, as one of the channels through which innovation flourishes in organizations (Sears and Baba, 2011). As creative individuals are employed following a selective hiring procedure, and following a proper induction and training, organizations can benefit from "exploratory learning" (Shipton et al., 2005) where ideas are flowing freely and risktaking is part of the cultural norms (Barros and Lazzarini, 202; Engel et al., 2015).

However, finding, selecting and recruiting high-quality and creative employees is not sufficient for stimulating innovation. As management scholars point out, firm policies need to also be "tuned" to match the work environment to the firm's strategic focus on innovation. Thus, a good mix of policies (e.g., autonomy, flexibility, trainings, leadership styles or information-sharing patterns) needs to be put in place for organizations to be fully taking advantage of the intrinsic creativity of their employees (Shalley, Zhou and Oldham, 2004; Wang and Cheng, 2010). Subsequently, one of the main organizational challenges for innovating firms is "to build room for individuality into the bureaucratic culture, to free the creative potential of the employee" (Evans, Farquhar and Landreth, 1989, p. 177) ${ }^{2}$. In this respect, the right mix of HR policies can provide

\footnotetext{
${ }^{2}$ A good example in this way is Google where, according to Forbes, the organizational culture puts a particular emphasis on encouraging creativity, prioritizing and actively encouraging innovation, allowing flexibility, communicating openly, and providing independence to employees, among other things (13 Reasons Google Deserves Its 'Best Company Culture' Award, 2018).
} 
organizations with multiple avenues to stimulate creativity, risk taking and overall innovativeness of their employees.

\subsection{Human resource policies and firm innovation}

Besides tapping into the creativity of employees, a firm's ability to innovate has also other important levers at the level of the organization (Amabile, 1988; Bloom et al., 2014) one of which is the use of dedicated HR practices (Bloom and Van Reenen, 2011). Coined as "the management

of work and people" (Boxall, Purcell and Wright, 2007), HR practices and systems have been linked to innovation performance of organisations across multiple disciplines.

For instance, Lan and Ngo (2004) take a look at the integration of HR practices into a system, and the role of organisational culture in determining the success of this system towards innovation of firms from Hong Kong. Shipton et al. (2006) examine longitudinally this question across 22 UK manufacturing companies, and find a positive relationship between HR practices and technological innovation. Similar effects are also found for both incremental and radical type of innovations produced by Beugelsdijk (2008) in a sample of Dutch firms, rounding up a consensus on the association between HR practices and innovation. In addition to examining direct effects, more recent contributions in this area focus on the interplay between various HR practices, bundling effects and commitments (Ceylan, 2013), combinations of HR policies (Andreeva et al., 2017) and the role of firm-specific idiosyncrasies and abilities, e.g., cooperation, skills and brokering aptitudes (Park et al., 2019). However, despite this wealth of knowledge, we still lack robust evidence both on the usefulness of HR policies for innovation in organizations and the contingencies which affect this relationship, particularly in an international, comparative context.

From a theoretical standpoint there are numerous arguments to support a clear and positive role for HR policies in both stimulating and supporting innovative performance of firms. Firstly, 
the resource based view of the firm (RBV) postulates that HR practices have a real potential to enhance creativity in an organization, and therefore increase innovation activities in the firm (Beugelsdijk, 2008). Hence, the design of work structures and job autonomy, flexible work schedules, training and performance-based pay, especially when combined, support the integration of knowledge, and thus creativity and innovation within the organization (Amabile et al., 1996; Bandiera, Barankay and Rasul, 2005; Kang, Morris and Snell, 2007; Wang and Cheng, 2010).

Secondly, from dynamic capability (DC) viewpoint, firms need to renew their competencies by “appropriately adapting, integrating, and reconfiguring internal and external organization skills, resources and functional competences to match the requirements of a changing environment" (Teece, Pisano and Shuen, 1997, p.515). Therefore, one cannot stimulate innovation absent of an HR policy structure in place which would allow both employees and management to pursue it also individually.

Finally, from an agency perspective we can conceptualize HR policies as a way to align the interests of employees and management (Jensen and Meckling, 1976; Barros and Lazzarini, 2012) which can then further foster innovation as a result of having common objectives, clear communication, and access to resources/support to achieve these goals (Huselid, 1995; Barros and Lazzarini, 2012; Zoghi, Mohr and Meyer, 2010). Overall, these different theoretical tenets support overwhelmingly the idea that organizations can trigger significant positive effects in terms of performance both at individual and organizational levels, simply by choosing and customizing its HR policies in light of its goals (Laursen and Foss, 2003; Zhu, Hong and Liu, 2013).

With this study we follow this line of inquiry, and in response to recent calls in the literature (Sparrow et al, 2016; Seeck and Diehl, 2017), we seek to deepen our knowledge on the direct effects of two such dimensions of HR policies (i.e., job autonomy and merit-based pay and promotion) on firm innovation and a couple of important external contingencies (competition from 
imports and labour regulations) that we believe will affect the relationship between HR policies and innovation. In the following sections we will develop theoretical rationales for these effects.

\subsection{Hypothesis development}

\subsubsection{Performance-based policies and firm innovation}

Pay and promotion based on merit, performance or achievements is a common way of rewarding above-average employees by making these rewards and the overall process more result-oriented. In addition to these direct benefits, such systems have been consistently shown to promote lower turnover rates among employees, as well as better financial performers of firms that adopt them (Huselid, 1995). With regards to innovation, PBP policies have been closely linked to extrinsic motivation, acting as a catalyst for employee creativity (Barros and Lazzarini, 2012) and "the types of innovative behavior that management requires" (Evans, Farquar and Landreth, 1989, p. 187).

However, despite these aforementioned benefits, the effect of PBP policies on innovation is still a subject of debate, particularly given some of the mixed empirical evidence on this issue (Laursen and Foss, 2003; Barros and Lazzarini, 2011). On one hand, performance-based pay policies undermine extrinsic motives and push people towards the "beaten path" and "traditional" methods instead of innovative yet riskier approaches, in order to maximize their income (Amabile, 1988; Shipton et al., 2006). In addition, since job performance is often a difficult and subjective metric, applying extrinsic rewards may hamper the creativity of people in complex and innovative jobs, where goal posts are more difficult to be observed or quantified (Shalley, Zhou and Oldham, 2004). Finally, another difficulty in providing a good link between performance and pay is the fact that nowadays most work tasks are performed in teams rather than individually, making it even

more difficult to isolate individual contributions to complex outcomes such as innovation 
(Bandiera, Barankay and Rasul, 2005: Krammer, 2021). All these arguments would suggest a rather murkier relationship between PBP policies and organizational innovation, particularly in settings where objectives/goals are more difficult to measure, where innovations are developed in large, heterogeneous teams and in contexts where innovation is less of a priority.

However, on the other hand, PBP policies present multiple and tangible benefits for organizational innovation. Such policies motivate employees to focus on a given target, and the recognition of their accomplishments in this area triggers a clear and positive response in terms of spurring firm innovation (Bandiera, Barankay and Rasul, 2005; Inderst, 2009). In addition, PBP policies also represent a very efficient selection mechanism (Bloom and Van Reenen, 2011) where least productive workers often leave the firm as a result of linking their compensation or promotion to certain goals, objectives and metrics. As a result of these shifts in the lower-end of the employees' productivity, a firm's efficiency and resource availability levels will improve automatically, commonly triggering increases in overall productivity and innovativeness of these organizations (Bloom and Van Reenen, 2011). Lastly, PBP measures have been found to promote the development of certain more radical and innovative ideas that facilitate innovation in technological, organizational and production areas of organizations, and subsequently boosting both the efficiency and profitability of these firms (Inderst, 2009).

Building on these arguments and given our focus on firm innovation we conjecture that this commitment is a strategic decision by the firm and congruence between its HR policies and its innovation strategies (i.e., R\&D investments) will be easier to reinforce each other (Zoghi, Mohr and Meyer, 2010). As a result, we expect HR policies such as performance-based pay and promotion to be useful segways for managers seeking to make a firm more innovative by enabling their employees to pursue and implement novel ideas. Thus, we posit that: 
Hypothesis 1: The use of promotion-based or performance-based pay policies by firms will be associated with a higher propensity to engage in innovation through $R \& D$ investment.

\subsubsection{Job autonomy and firm innovation}

Arguments from RBV and dynamic capabilities theories suggest that policies concerning job autonomy (JA) will impact organizational innovation through several mechanisms. First, autonomy can act as an extrinsic motive, so it can be used with relative ease as component of the reward system to promote innovative activities (Mumford, 2000). Second, JA can lead to significant improvements in terms of efficiency by delegating to a large extent this decision to each employee. As a result, determining one's own tasks and projects, work hours, deadlines, and working pace within a reasonable frame can lead to an effective distribution of tasks within the organization. Regarding innovation, it can trigger self-selection of individuals into teams and projects, based on their affinity, attractiveness and perceived contributions, which often result in better chances to innovate (Krammer et al., 2019).

Third, job autonomy comes together with more employee empowerment, which means that employees enjoy more flexibility in reacting to changes and uncertainty (Beugelsdijk, 2008). As such, JA is a vital avenue for innovation as "job-related problem solving has been found to be the most important aid in helping professional personnel keep abreast of developments in their fields" (Allen and Katz, 1989, p. 196). Without significant levels of JA, employees have to rely more on organizations to provide them a roadmap in terms of achievable expectations and goals in terms of innovation. In addition, JA allows employees to fully take advantage of their intrinsic creative or innovative traits, and thereby maximizing their individual innovation performance as well as that of the organizations to whom they belong to (Cai, Song and Zhao, 2013). 
Lastly, another benefit of JA is decentralization and a flattened organizational hierarchy which often results in more innovation. The more autonomy the workers gain, the more control they have over the decisions regarding tasks and working conditions (Bloom and Van Reenen, 2011). Determining the degree of decentralization, the hierarchy of the firm makes an important decision, because giving up authority at the management level means that "problem-solving rights are delegated to the shop floor" (Laursen and Foss, 2003, p.248). If employees enjoy managerial support in finding their own solutions to problems, this will lead to employees collecting, organizing and, most importantly, using more and more information and knowledge from different parts of the firm (Lee and Kelley, 2008). Ultimately, this process fosters not only effectiveness of organizations, but also their commitment to innovation (Zoghi, Mohr and Meyer, 2010).

Considering all these rationales we propose that:

Hypothesis 2: The use of job autonomy policies by firms will be associated with a higher propensity to engage in innovation through $R \& D$ investment.

\subsubsection{The role of the competitive environment}

The competitive environment is a crucial determinant of firm success. While very high levels of competition might be detrimental for firms' productivity and innovation orientation (Aghion et al., 2005), most markets and niches exhibit a positive relationship between the degree of market competition and innovation as a result of unlocking creative and entrepreneurial forces (Zehra and Garvis, 2000; Krammer, 2009) as well as a tighter coupling between firm structure and strategies (Burton and Obel, 2018), and in this case, HR policies and innovation strategy (Brusoni and Prencipe, 2013). In particular, the nature of competition from foreign-produced goods and services faced by firms shifts their focus from price considerations to technological sophistication and quality rationales (Fan et al., 2015; Bajgar and Javorcik, 2020). Subsequently, competitive 
environments (particularly from imported foreign products that usually have an technological edge) can trigger significant reactions from firms in terms of HRM and innovation strategies (Nocco et al., 2019; Traiberman, 2019). Thus, competition from imports will weaken the perceived effect of performance-pay HR policies on innovation for several reasons.

First, import competition will increase the pressure on local incumbents to reduce costs or upgrade their products. In turn, such competition will leave less leeway for incumbent firms to attract and motivate their employees through performance-pay incentives, as most efforts will be directed towards fighting for market share (Pudelko and Harzing, 2007). Second, the enhanced risk in innovating may reduce the firm's strategic rationales and personal enthusiasm for increasing pay for employees' performance in the uncertain process of innovation (Florida, 2006). Subsequently, this will trigger a response to focus on core-competences and markets as opposed to exploration of new activities via innovation (Anand et al., 2009). Finally, a well-known outcome from the literature is that domestic firms often believe that the return from innovation will be jeopardised in a hostile competitive situation (Greenhalgh and Rogers, 2006). In this case, competition from exports involves foreign-based firms that have a competitive edge either in terms of technology or in terms of costs, both of which will trigger a negative reaction from domestic firms in terms of stimulating their employees via performance-based mechanisms (Liu, 2008).

In turn, we expect that competitive pressure from imports will positively moderate the effects of job autonomy on innovation for several reasons. In the first instance, import competition will trigger a greater necessity to attract, retain and motivate highly capable employees (Bloom et al., 2010). Thus, greater competition from imports and foreign firms will increase the incentives for domestic firms to recruit and retain high quality human capital without competing on wages. Job autonomy provides an attractive alternative for domestic firms to do so and offers additional slack which may be redirected for innovative activities, such as R\&D (Li, Zhao, and Liu, 2006). 
Second, job autonomy can provide an alternate way for firms to retain key workers and in the face of import competition, the role of the latter in stimulating innovation will become even more critical. Hence, by providing greater autonomy, a firm facing this type of competition will entrust its key employees with greater responsibilities and leeway in terms of how to tackle daily challenges (Purcell and Hutchinson, 2007). These could constitute important advantages in highly dynamic and great growth potential environments, such as emerging markets, where highly-skilled human capital is rather scarce and at a premium for innovating firms (Krammer, 2009).

Summing up, we propose that:

Hypothesis 3: The competitive context (i.e., intensity of competition from imports) will negatively moderate the relation between performance based pay policies and a firm's propensity to engage in innovation through $R \& D$ investment $(\mathrm{H} 3 \mathrm{a})$, and respectively positively moderate the relation between job autonomy policies and firm's propensity to engage in innovation through $R \& D$ investment $(H 3 b)$.

\subsubsection{The role of the institutional environment}

According to the institutional theory (North, 1990; Scott, 2001) firms respond to both formal and informal institutional stimuli by adopting certain behaviors and strategies which fit the rules, regulations, norms and cultural idiosyncrasies of countries in which they operate. Following these insights, we examine the a specific institutional feature (i.e., stringency of labour regulations) that is particularly salient for our phenomenon of interest (i.e., HR policies). We therefore argue that the stringency of labour laws in a country will moderate, although in different ways, the effects of HR policies on firm innovative endeavours.

There are several reasons for which the effect of performance-based pay policies on innovation will be weaken by more stringent and detailed labour regulations. First, while tighter 
labour regulations in a country will have desirable societal benefits by reducing income dispersion (Adams and Deakin, 2014), in our case, they will likely diminish the ability of firms to motivate employees to take risks and innovate in these environments (Haucap and Wey, 2004). Second, this decrease in the scope for performance-based pay will result in less interest and personal investments from employees in developing innovations in these firms, and subsequently, thereby weakening the effect of performance-based pay on firms' innovative investments (Gooderham, Nordhaug and Ringdal, 1998). Finally, stringent labour regulations will also reduce a firm's ability to attract, select, and retain creative and innovative employees on competitive bases, such as abovemarket salaries and bonuses that are contingent on personal performance or targets (Acharya, Baghai, and Subramanian, 2013). Hence, more stringent wage regulations in a country will ultimately improve inequality in a society but likely decrease (i.e., weaken) firms' ability to employ performance-based policies to pursue novel ideas and innovations for future commercial gains (Aghion et al., 2019).

In turn, more stringent labour regulations will have the opposite effect (i.e., strengthen the impact) on the relation between job autonomy HR policies and firm innovation for the following reasons. First, stringent regulations will provide strong guarantee for employees' rights and job protection which in turn will provide them more leeway towards pursuing riskier, more creative, and explorative endeavors that otherwise would not have been possible (Towse, 2001). Second, the empowerment effect that accompanies job autonomy providing more flexibility and scope for reaction to change and uncertainty (Beugelsdijk, 2008) will be reinforced by strong institutional provisions regarding the protection of employees. As such, while many of these endeavors could end up in failure, this greater flexibility through HR policies and the stronger job protection via institutionalized labour practices will provide employees greater scope to pursue more innovative and riskier endeavours that will likely increase the overall firm's innovation performance (Rodrigo- 
Sanbartolomé, 2020). Finally, more stringent labour regulations will also enhance the benefits of flatter hierarchical structures in terms of less red-tape or approvals for undertaking innovative projects by further promoting individuals to pursue such endeavours within the scope of their regular roles and without significant organizational frictions (e.g., approvals, bureaucratic hurdles) that characterize organizations with more hierarchical structures (Pichault and McKeown, 2019).

Given all these effects, we hypothesize that:

Hypothesis 4: The institutional context (i.e., the stringency of labour regulations) will negatively moderate the relation between performance-based pay policies and a firm's propensity to engage in innovation through $\mathrm{R} \& D$ investment $(\mathrm{H} 4 \mathrm{a})$, and respectively positively moderate the relation between job autonomy policies and firm's propensity to engage in innovation through $R \& D$ investment $(H 4 b)$.

\section{METHOD}

\subsection{Data and sample}

We employ data from the Management, Organization and Innovation (MOI) Survey, conducted by the European Bank for Reconstruction and Development (EBRD) and the World Bank (20082009). This dataset has been previously employed for examining firm innovation across countries (Maksimov, Wang and Luo, 2017; Nuruzzaman, Gaur and Sambharya, 2019; Bahl, Lahiri and Mukherjee, 2020). The survey covers manufacturing firms from 10 emerging economies from Eastern Europe and Central Asia (e.g., Belarus, Bulgaria, Kazakhstan, Lithuania, Poland, Romania, Russia, Serbia, Ukraine and Uzbekistan), plus Germany and India. After eliminating all missing observations for our main variables of interest from the dataset, we are left with answers from more than 1200 firms across 12 countries. Finally, data regarding import competition is not available/reported for some of the firms in our sample which leaves us with a sample of 944 firms 
for testing those particular specifications/models. Table 1 presents the descriptive statistics and the matrix of pairwise correlations for all these variables.

--- Table 1 here ---

Dependent variable. Following previous literature we capture firm innovation using a binary variable $(R D)$ which measures whether the firm invests or not in $\mathrm{R} \& \mathrm{D}$ activities (e.g. Wakelin, 1998; Lederman, 2010; Santiago, 2013; Krammer, 2019). In addition to this variable, we employ also an alternate measure for innovation (i.e., patents), as detailed in the robustness section.

--- Table 2 here ---

\section{Explanatory variables.}

To capture various dimensions of HR policies using different questions in the MOI survey we employ PCA (Principal Component Analysis), which has been previously used in this literature for similar data reduction purposes (Laursen and Foss, 2003; Beugelsdijk, 2008). We start with 7 potential variables to capture PBP and JA policies using PCA with orthogonal varimax rotation to better fit the data (Abdi and Williams, 2010). For a detailed description of these variables please see Table 3. Four of these 7 items loaded into two factors with Eigen values greater than 1 which we identify as PBP and JA components of HR policies (Table 2). The results confirm two variables that capture job autonomy (JA): taskallocation, which takes the values 1-5 depending on who determines the allocation of tasks for workers, 1 being only factory managers and 5 if it is only the workers decision (and 3 being when the two parties participate equally in the decision-making). The second variable is pacework, which is also a Likert variable with values between 1 and 5 , measuring who sets the pace of work at the establishment, in similar fashion to the allocation of tasks. For performance-based pay and promotion (PBP) policies, two indicators load up on this factor: (1) whether financial rewards are given when production targets are reached (prodreward) 
and (2) whether rewards are widely distributed (staffreward, which equals 1 if all workers are rewarded upon target achievement, and 0 if only management receives rewards).

--- Table 3 here ---

To measure competitive pressures from imports (Import_compet) we use a question from the MOI survey which asks: "Do you compete with imports from abroad in your main product market?" Subsequently, we code all "yes" answers to this question as 1 , and "no" answers as 0 . All "I don't know" answers are discarded from our sample.

Finally to capture the stringency of labour regulations we use the index developed by Botero, Djankov, La Porta, Lopez-de-Silanes and Shleifer (2004). This index captures different aspects of regulation of labour markets in 85 countries worldwide, which makes it particularly useful for cross-country comparisons as is the case here. Specifically the index (Labour_regul) covers three broad areas (1-employment laws; 2-collective relations laws, and 3-social security laws) which are then quantified through a variety of indicators from different sources ${ }^{3}$. This index has been extensively used both in economics and management studies seeking to compare and contrast labour regulations across countries (e.g., Levie and Autio, 2011; Van Hoorn, 2014; Bauer et al., 2018). Higher values of this index mean more stringent labour regulations in place. For instance Tunisia scores the highest $(0.816)$ on this index, followed by Portugal $(0.809)$, while Zambia (0.148) and Japan (0.164) score the lowest. The mean for all countries is 0.475 (Botero et al., 2004), while in our sample of countries the mean of this variable is 0.732 .

Control variables. To control for other factors affecting firm's innovation (i.e., R\&D investment) we add a set of control variables that have been found or are suspected to affect innovation activities of a firm by previous research (e.g. Bloom and Van Reenen, 2011; Zhou, Hong and Liu, 2013).

\footnotetext{
${ }^{3}$ For more details on the exact construction of the index please consult Botero et al. (2004).
} 
These are standard controls in the literature, such as firm size - measured by the number of fulltime employees log transformed (ln_size), firm age (ln_age), foreign ownership dummy (foreign_own), state ownership dummy (state_own), degree of perceived competition (competition), and whether the firm has multiple establishments (multiest). In addition we include both industry-(at the level of 2-digit ISIC codes) and country fixed-effects to control for unobserved heterogeneity across firms.

\subsection{Empirical specification}

Given the binary nature of our dependent variable (RD) we employ probit models in order to estimate the effects of the explanatory variables on our main proxy for firm innovation, i.e., $R \& D$ spending (Lederman, 2010; Krammer, 2019). Formally, we estimate the effect of management policies using the following equation:

$$
\begin{gathered}
R D_{i}=\beta_{0}+\beta_{1} P B P+\beta_{2} J A+\beta_{3} P B P * \text { Import_compet }_{i}+\beta_{4} J A * \text { Import_compet }_{i}+\beta_{5} P B P \\
* \text { Labour_regul }+\beta_{6} J A * \text { Labour_regul }_{c}+\lambda_{n} \text { control variables } \\
+\sigma_{k} \text { industry }+\varphi_{l} \text { country }+\varepsilon_{i},
\end{gathered}
$$

where $i$ denotes a particular firm.

\subsection{Analysis and results}

The results of our estimations are presented in Table 4. In addition, we discuss (but do not report here due to space constraints) marginal effects for all these variables.

--- Table 4 here ---

Overall, the results of the control variables and in line with our expectations, and they remain constant throughout our models (Model 1). Specifically, we find that bigger firms are more likely to invest in $\mathrm{R} \& \mathrm{D}$ as opposed to smaller ones, and competition seem to also have a positive 
but weak effect on firms' propensity to invest in R\&D. Finally, the lack of statistical significance for many of these variables is driven by the inclusion of both country and industry fixed effects which is able to explain a lot of the variation across firms in terms of engagement in R\&D. In Model 2 we test our first hypothesis, namely the role of performance-based pay (PBP) policies. The coefficient of this variable is positive and highly statistically significant at less than 1 percent, thus confirming our Hypothesis 1. Overall, this result suggests that firms that employ more extensively PBP policies are more likely to engage in innovation by investing in R\&D. Next we test our second hypothesis by analyzing job autonomy (JA). Again, the coefficient of this variable is positive and highly statistically significant at 5 percent, suggesting that greater job autonomy is positively associated with better innovative performance, i.e., greater likelihood of investing in R\&D activities. The coefficients hold both in terms of magnitude and statistical significance, suggesting that PBP and JA are distinct HRM measures that contribute additively to better firm innovative performance (Model 4).

Models 5 and 6 test the potential moderating effect of external environment via an economic element, namely the competition from imports (Import_compet). We notice that the direct effect of this variable is positive and highly significant, appearing to complement and have a much larger magnitude than generic competition, which was used as a control in all our estimations. In terms of hypothesis testing, we find out that the coefficient of the interaction between import competition and performance pay is negative and statistically significant at 10\% (Model 5) suggesting that reliance on performance pay schemes are weakly detrimental for a firm when facing severe competition from foreign owned firms. Nevertheless, the coefficient of the interaction between job autonomy and import competition is positive and significant at 5\% suggesting that in such environments, firms would gain in innovation terms through greater job autonomy (Model 6). 
Models 7 and 8 test the potential moderating effect of external environment via an institutional element that is salient for HRM, namely the regulation of labour in these countries (Labour_regul). While our results overall suggest no strong direct relationship between labour regulations and firm innovation, labour regulation has a positive moderation effect on the relationship between job autonomy and innovative performance, in the sense that it enhances the effects of the latter (Models 8). For performance based pay, we do not find any significant moderating effects of labour institutions (Models 7). Finally, we include all variables and all interactions in a very conservative test of the robustness of these results (Model 9). The coefficients of our hypothesized direct and interaction effects hold to this test, despite losing some statistical significance (as expected) due to the saturation of these models and also the rise in terms of collinearity which pushes up standard errors of the point estimates.

\subsection{Robustness checks}

To check the robustness of our conclusions regarding the importance of HR policies more broadly for innovation, we employ several additional tests.

First, we use an alternate proxy for innovative performance, namely a measure of patenting activities of the firm (patents), as common proxy for innovation output, particularly in emerging and less developed markets where firms seldom patent abroad (e.g. Lederman, 2010; Furman, Porter and Stern, 2002; Krammer, 2014). This variable takes the value of 1 if the firm has registered any patents in its home country in the past year, and 0 if it has no patents (obtained also from the MOI Survey). The results of these additional regressions and marginal effects mirror our findings concerning R\&D investment. They are not reported here due to space constraints but are available upon request. Magnitude-wise, the computed marginal effects indicate that a 1 unit change in JA (respectively PBP) leads to a 2.5 (respectively 2.4) percent increase in the probability of obtaining 
a patent in the home country of the firm. Thus, these findings confirm to the role of HR policies in stimulating broadly innovation, both through engagement/commitments to innovative activities (i.e., R\&D investments) as well in terms of its commercial outcomes (i.e., patents).

Second, we also need to be mindful of any potential clustering effects occurring within our data, given its structure, namely firms being clustered within countries that are geographically segregated and also differentiated in terms of institutions, conditions for innovation, or cultural norms that affect HRM practices, etc. To account for potential clustering effects, we have carried out also estimations using a random-intercept mixed-effects (or hierarchical) multilevel probit model $^{4}$. Specifically, we have modelled firm level innovation as nested in a given country $\mathrm{j}$ (Raudenbush and Bryk, 2002; Snijders and Bosker, 2011). Thus, we apply the following econometric model where firms are level 1 units, they are nested within countries (level 2 units):

$$
R D_{i c}=\beta_{0}+\sum_{h=1}^{s} \beta_{h} x_{h i c}+E_{i c}+C_{0 i}
$$

RD is the binary dependent variable for innovation -whether a firm i operating in a country c invests in $\mathrm{R} \& \mathrm{D}$ or not. The $\beta_{0}$ is the intercept, $\beta_{h}$ are fixed effects (or "regular" regression estimated coefficients, and $x_{h i c}$ are independent or explanatory variables in our model. $E_{\text {irc }}$ are firm (level 1) residuals, while $C_{0 i}$ are random-effects accounting for firm variation within firms which are nested within countries. The interclass correlation coefficients suggest that about 7.09 percent of the variance in our DV comes from country-level factors, in comparison to 35.83 percent from firmlevel factors. These numbers suggest that multi-level regression does improve our explanatory power in a rather marginal fashion. Moreover, these regression results (available in Table A3 in

\footnotetext{
${ }^{4}$ We would like to thank to one of the reviewers for making this suggestion.
} 
Appendix A) confirm our main conjectures in regard to the role of $\mathrm{HR}$ policies towards firm innovation and their interplay with the institutional and economic external environment of the firm.

\section{DISCUSSION AND CONCLUSIONS}

This work was motivated by two important rationales. First, to move beyond single-country studies and generalize the importance of HR policies for a key strategic area of firm performance, i.e., innovation (Lederman, 2010; McCann and Oxley, 2012) and second, to investigate how contextual conditions affect the relationship between HR policies and firm innovation. Remarkably, both of these questions remain unanswered by $\mathrm{HR}$ and innovation management scholars alike, and this attempt seeks to integrate these two rich yet unconnected streams of literature. In addition, given the significance variance in terms of economic and institutional environments around the world, we also seek to take advantage of this heterogeneity and achieve better generalizability regarding the effects of HR policies on innovation by testing these relationships in a trully international setting.

To this end, we develop theoretical arguments that focus on two central themes of HR policies, namely performance-based pay (PBP) and job-autonomy (JA). Our arguments postulate that both of these factors will positively influence a firm's ability to innovate. Furthermore, using elements from institutional theory we argue that the economic and institutional environment in which these firms are active will have an impact on the efficiency of these HR policies in spurring firm innovation. Our empirical setting employs a dataset of more than 900 firms across 12 countries, most of them emerging markets. The seven variables (each measuring management policies) introduced to the PCA loaded up to two components that were tested in a probit model to analyze their impact on innovation, measured by R\&D investments. The results broadly support 
our theoretical conjectures. Specifically, firms granting more autonomy for workers, giving performance feedback regularly and assessing bonuses and promotions based on the individual's performance are more likely to engage in $R \& D$ (and patenting) and thus are more innovative than those not applying any of these HR policies. Moreover, import competition moderates negatively (i.e., weakens) the effects of PBP on innovation and positively (i.e., strengthens) the effects of JA on innovation. In turn, the quality of labour regulations in place moderates positively (i.e., strengthens) the effects of JA on innovation.

Subsequently we propose three key contributions. First, we theorize and test empirically the interplay between firms' HR strategies and the contextual macro-environment in which they operate, by focusing on both economic and institutional tensions. In this way we are able to augment the existing literature by shedding light on the complex interactions between firms and the environment in which they operate (Kochan and Bamber, 2009). Specifically, we find that competitive pressures from imported goods and services (Nocco, Ottaviano and Salto, 2019; Traiberman, 2019) moderate the effects of HR policies on firm innovation. This suggest that in addition to internal factors that were explored by prior literature - e.g., organizational culture or management skills (Lau and Ngo, 2004; Park et al., 2019)- external factors (to the firm) also play a role in determining how efficient their HR policies will be in stimulating their innovation.

Second, following recent calls in the literature to examine the role of formal and informal institutional settings in determining firm innovation (Krammer, 2019) we take a closer look at the role of formal regulations regarding labour in moderating the effects of HR policies such as performance based pay and job autonomy. In doing so we provide evidence that institutions matter also from the perspective of efficacy of HR policies, suggesting a delicate mix or balance to be required for firm innovation and its subsequent performance (Fuentelsaz et al., 2020). 
Third and final, we examine theoretically and test empirically the effect of two HR policies (i.e., job autonomy and pay/promotion incentives) on firm innovation via both inputs (i.e., R\&D investments) and outputs of this process (i.e., patents). We are doing so in an international and comparative setting of 12 countries, which is advances the generalizability of our conclusions compared with prior studies that have usually been confined to firms in a single country (e.g., Lau and Ngo, 2004; Beugelsdijk, 2008; Ceylan, 2013; Andreeva et al, 2017).

Our results showcase the importance of performance-based pay policies. While there is strong theoretical consensus for the role of PBP for firm performance, including innovation, empirical findings in this area remain rather inconclusive, often reporting ambiguous or contradictory results (e.g. Shalley, Zhou and Oldham, 2004; Bandiera, Barankay and Rasul, 2005; Inderst, 2009). This strong positive result attests the importance of PBP policies in a wider and international context, thus contributing to debate about how extrinsic motives hinder the creativity of workers by pushing them to safe solutions and supporting the idea of an extrinsic motive to further foster creativity and innovation within organizations (Barros and Lazzarini, 2012).

Our findings regarding job autonomy complement the scarce evidence in this area (Mumford, 2000; Beugelsdijk, 2008; Zoghi, Mohr and Meyer, 2010). It is important to see the channels through which increased autonomy encourages innovation, e.g. decisions on allocating tasks and setting the pace of work. Our results confirm a positive and strong link between job autonomy and organizational innovation likely through employee creativity and proactive risk taking. Dissolving the rigidities of splitting responsibilities for certain tasks in a pre-defined manner, and allowing for a little flexibility in setting the pace of work can give the confidence to workers to try new ideas or explore new possibilities (Shipton et al., 2005).

Lastly, we are able to also confirm the complementary role of different HR policies as envisioned by the proponents of the HR systems theory (Park et al., 2019): our results suggest that 
PBP and JA contribute in a positive and joint manner to firm innovation. While their individual impact is positive and significant we find no evidence of trade-offs, overlap or inefficiencies in terms of combining these policies. This is also consistent with the idea of more practices-better outcome promoted by Laursen and Foss (2003) in their influential HRM study.

This research presents several practical implications for both managers and policy-makers. For the former, they need to configure their HR policies in such a way that they emphasize autonomy and performance-based measures as a way not only to incentivize employees to perform, but also stimulate the innovative performance of these firms. Clearly, these practices need to be implemented with flexibility such that well-performing employees are also granted greater autonomy to undertake and develop new business initiatives which in turn will drive innovation in these organizations. Complementarily, our results suggest significant contingencies to the effects of $\mathrm{HR}$ practices on firm probability to engage in innovation via $\mathrm{R} \& \mathrm{D}$ investments. We find that while greater competition from external (imported) products is associated with R\&D investments, it also reduces the benefits of having performance based incentives. This provides evidence of a "double-edge sword" effect of stimulating or liberalizing markets for foreign firms and imports which is of interest to policy makers. In turn, greater import competition further amplifies the benefits of firms that have job autonomy policies in place. Finally, our results confirm a boosting effect for job autonomy measures concerning innovation from better labour regulations, suggesting again an avenue for policy makers to improve the innovativeness of their domestic firms by streamlining and making more flexible labour regulations in a given country.

Notwithstanding the merits of this work, we also need to acknowledge some of its limitations. First, as briefly noted before, the results do not justify the notion that there exists a set of universal "best practices" that work in all situations - they might as well only be applicable solely to emerging economies and the manufacturing industry, which is certainly a limitation, but 
also a possibility for future research by testing them in different settings. Second, as innovations are more and more related to intellectual property and know-how, it would be interesting to see a similar analysis carried out in the service industry, which is heavily pressured by the need for novelty and innovation. Another interesting direction for future research could be the testing of other proxies for innovation, particularly in the case of greater industry coverage. Third, our measure for R\&D makes only a binary distinction between firms, which is robust in this sample, but also limits the extent of conclusions drawn from the results. In addition, R\&D investment is measured only in one year limiting the available information (variance) within firms in terms of innovation investments across time. Better and more detailed indicators for innovation, unfortunately not avaible presently, could provide more insight into the economic magnitude and importance of HR policies for innovation and other firm outcomes. Fourth, similar to other recent studies who employ the MOI data (Maksimov et al., 2017; Bahl et al., 2020), we are bounded by the inherent limitations of this survey, namely its age (over a decade old now) and phrasing of available questions (usually in a binary yes/no manner and covering only one year, either past on current one). Given the research interest shown by different scholarly communities (i.e., innovation, international business, strategy) for this dataset, another round of MOI surveys would make a very welcomed opportunity for scholars across all these disciplines disciplines. Finally, from a myriad of contextual factors to be considered, we have focused on only two economic and institutional elements, which we deemed to be particularly salient for our research question. However, this consideration is by no means exhaustive; a future opportunity for researchers interested in this topic is to analyze and theorize the significance of other contextual factors which have not been covered in this study, such as political contexts, governmental support (through tax breaks or subsidies) or product regulations and approval procedures. 
To conclude, this study demonstrates that HR policies are valuable instruments for firms seeking to spur their innovative performance and in doing so their competitive advantage in markets. It also showcases the importance of external factors of economic and institutional nature that can both strengthen and weaken the effects of HR policies on innovative performance of firms. 


\section{REFERENCES}

Abdi, H. and Williams, L. J. (2010): Principal component analysis. Wiley Interdisciplinary Reviews: Computational Statistics. Vol. 2, Issue 4, July-August 2010, pp. 433-459

Acharya, V. V., Baghai, R. P., \& Subramanian, K. V. (2013). Labor laws and innovation. The Journal of Law and Economics, 56(4), 997-1037.

Adams, Z., and Deakin, S. (2014). Institutional solutions to precariousness and inequality in labour markets. British Journal of Industrial Relations, 52(4), 779-809.

Aghion, P. and Blanchard, O.J. (1998): On privatization methods in Eastern Europe and their implications. Economics of Transition, Volume 6(1), pp. 87-99

Aghion, P., Akcigit, U., Bergeaud, A., Blundell, R., and Hémous, D. (2019). Innovation and top income inequality. The Review of Economic Studies, 86(1), 1-45.

Allen, T. J. and Katz, TR. (1989): Managing engineers and scientists: some new perspectives in P. Evans, Y. Doz and A. Laurent. Human Resource Management in International Firms: Change Globalization, Innovation, London: Macmilb pp. 191-200

Amabile, T.M. (1988): A model of creativity and innovation in organizations. Research in Organizational Behavior, Vol. 10, pp. 123-167

Amabile, T.M., Conti, R., Coon, H., Lazenby, J. and Herron, M. (1996): Assessing the Work Environment for Creativity. Academy of Management Journal, 1996, Vol. 39, No. 5, pp. 1154-1184

Anand, J., Mesquita, L. F., \& Vassolo, R. S. (2009). The dynamics of multimarket competition in exploration and exploitation activities. Academy of Management Journal, 52(4), 802-821.

Andreeva, T., Vanhala, M., Sergeeva, A., Ritala, P., \& Kianto, A. (2017). When the fit between HR practices backfires: Exploring the interaction effects between rewards for and appraisal of knowledge behaviours on innovation. Human Resource Management Journal, 27(2), 209227.

Aw, B. Y., Roberts, M. J., \& Xu, D. Y. (2011). R\&D investment, exporting, and productivity dynamics. American Economic Review, 101(4), 1312-44.

Bahl, M., Lahiri, S., \& Mukherjee, D. (2020). Managing internationalization and innovation tradeoffs in entrepreneurial firms: Evidence from transition economies. Journal of World Business, 56(1), 101-150.

Bajgar, M., \& Javorcik, B. (2020). Climbing the rungs of the quality ladder: FDI and domestic exporters in Romania. The Economic Journal, 130(628), 937-955.

Bandiera, O., Barankay, I. and Rasul, I. (2005): Social Preferences and the Response to Incentives: Evidence from Personnel Data. The Quarterly Journal of Economics, Vol. 120, No. 3 (Aug., 2005), pp. 917-962

Barros, H.M. and Lazzarini, S.G. (2012): Do Organizational Incentives Spur Innovation? BAR, Rio de Janeiro, Vol. 9, No. 3, Art. 4, pp. 308-328

Bauer, F., Schriber, S., Degischer, D., \& King, D. R. (2018). Contextualizing speed and crossborder acquisition performance: Labor market flexibility and efficiency effects. Journal of World Business, 53(2), 290-301.

Berraies, S., Chaher, M., \& Yahia, K. B. (2014). Employee empowerment and its importance for trust, innovation and organizational performance. Business Management and Strategy, 5(2), 82-103.

Beugelsdijk, S. (2008): Strategic Human Resource Practices and Product Innovation. Organization Studies 29(06), pp. 821-847

Bjørnskov, C. and Potrafke, N. (2011): Politics and privatization in Central and Eastern Europe. A 
Bloom, N. and Van Reenen, J. (2011): Human Resource Management and Productivity. In: Handbook of Labour Economics, Vol. 4, Part B, 2011, pp. 1697-1767.

Bloom, N., Lemos, R., Sadun, R., Scur, D. and Van Reenen, J. (2014): The new empirical economics of management. NBER Working Paper Series, No. 20102, 2014

Bloom, N., Sadun, R. and Van Reenen, J. (2010): Does Product Market Competition Lead Firms to Decentralize? American Economic Review: Papers \& Proceedings 100 (May 2010), pp. 434-438.

Botero, J. C., Djankov, S., Porta, R. L., Lopez-de-Silanes, F., \& Shleifer, A. (2004). The regulation of labor. The Quarterly Journal of Economics, 119(4), 1339-1382.

Brusoni, S., \& Prencipe, A. (2013). The organization of innovation in ecosystems: Problem framing, problem solving, and patterns of coupling. In Collaboration and competition in business ecosystems. Emerald Group Publishing Limited.

Burton, R. M., \& Obel, B. (2018). The science of organizational design: fit between structure and coordination. Journal of Organization Design, 7(1), 1-13.

Cai, W., Song, W., \& Zhao, S. (2013). An empirical study on the effects of creative personality and job autonomy on individual innovation performance of knowledge workers. International Business and Management, 6(2), 24-30.

Ceylan, C. (2013). Commitment-based HR practices, different types of innovation activities and firm innovation performance. The International Journal of Human Resource Management, 24(1), 208-226.

Chiang, Y.H. and Shih, H.A. (2011), "Knowledge oriented human resource configurations, the new product development learning process, and perceived new product development", The International Journal of Human Resource Management, Vol. 22 No. 15, pp. 3202-3221.

Cohen, W.M. and Levinthal, D.A. (1990): Absorptive Capacity: A New Perspective on Learning and Innovation. Administrative Science Quarterly, Vol. 35, No. 1, Special Issue: Technology, Organizations, and Innovation (Mar., 1990), pp. 128-152.

Coombs, J.E. and Bierly, P.E. III (2006) Measuring technological capability and performance. $R \& D$ Management, 36, 421-438.

Danneels, E. (2002). The dynamics of product innovation and firm competences. Strategic management journal, 23(12), 1095-1121.

Engel, K., Dirlea, V., Dyer, S. and Graff, J. (2015): How to build the permanently innovative company: Five tested sets of management practices. Strategy \& Leadership, Vol. 43, Issue 1, pp. 3-10

Evans, P., Farquhar, A. and Landreth, O. (1989): Fostering Technological Inovation in Large Complex Firms: The contribution of Human Resource Management in P. Evans, Y. Doz and A. Laurent. Human Resource Management in International Firms: Change Globalization, Innovation, London: Macmillan pp. 191-200.

Fan, H., Li, Y. A., \& Yeaple, S. R. (2015). Trade liberalization, quality, and export prices. Review of Economics and Statistics, 97(5), 1033-1051.

Forbes, 2018. 13 Reasons Google Deserves Its 'Best Company Culture' Award.

Available: https://www.forbes.com/sites/forbestechcouncil/2018/02/08/13-reasons-googledeserves-its-best-company-culture-award

Florida, R. (2006). The flight of the creative class: The new global competition for talent. Liberal Education, 92(3), 22-29.

Furman, J.L., Porter, M.E. and Stern, S. (2002): The determinants of national innovative capacity. Research Policy 31 (2002), pp. 899-933. 
Fuentelsaz, L., Garrido, E., \& Maicas, J. P. (2020). The effect of informal and formal institutions on foreign market entry selection and performance. Journal of International Management, 26(2), 100735.

Glaister, A. J., Karacay, G., Demirbag, M., and Tatoglu, E. (2018). HRM and performance-The role of talent management as a transmission mechanism in an emerging market context. Human Resource Management Journal, 28(1), 148-166.

Gooderham, P., Nordhaug, O., and Ringdal, K. (1998): When in Rome, do they do as the Romans? HRM practices of US subsidiaries in Europe. Management and International Review, 38(2): 47-64.

Goedhuys, M. (2007). Learning, product innovation, and firm heterogeneity in developing countries; Evidence from Tanzania. Industrial and Corporate Change, 16(2), 269-292.

Greenhalgh, C., \& Rogers, M. (2006). The value of innovation: The interaction of competition, R\&D and IP. Research Policy, 35(4), 562-580.

Haucap, J., \& Wey, C. (2004). Unionisation structures and innovation incentives. The Economic Journal, 114(494), C149-C165.

Heij, C. V., Volberda, H. W., Van den Bosch, F. A., and Hollen, R. M. (2020). How to leverage the impact of R\&D on product innovation? The moderating effect of management innovation. R\&D Management, 50(2), 277-294.

Hitt, M. A, M. T Dacin, E. Levitas, J. L Arregle, and A. Borza. 2000. "Partner Selection in Emerging and Developed Market Contexts: Resource-based and Organizational Learning Perspectives." The Academy of Management Journal 43 (3): 449-467.

Huselid, M.A. (1995): The Impact of Human Resource Management Practices on Turnover, Productivity, and Corporate Financial Performance. Academy of Management Journal, 1995, Vol. 38, No. 3, pp. 635-672

Inderst, R. (2009): Innovation management in organizations. European Economic Review 53 (2009), pp. 871-887

Jensen, M.C. and Meckling, W.H. (1976): Theory of the Firm: Managerial Behavior, Agency Costs and Ownership Structure. Journal of Financial Economics 3 (1976), pp. 305-360

Kafouros, M., Aliyev, M., \& Krammer, S. M. (2021). Do firms profit from patent litigation? The contingent roles of diversification and intangible assets. Research Policy, 50(6), 104263.

Kang, S.-C., Morris, S.S. and Snell, S.A. (2007): Relational Archetypes, Organizational Learning and Value Creation: Extending the Human Resource Architecture. Academy of Management Review, 2007, Vol. 32, No. 1, pp. 236-256

Krammer, S. M. (2009). Drivers of national innovation in transition: Evidence from a panel of Eastern European countries. Research Policy, 38(5), 845-860.

Krammer, S. M. (2014). Assessing the relative importance of multiple channels for embodied and disembodied technological spillovers. Technological Forecasting and Social Change, 81, 272-286.

Krammer, S. M. (2015). Do good institutions enhance the effect of technological spillovers on productivity? Comparative evidence from developed and transition economies. Technological Forecasting and Social Change, 94, 133-154.

Krammer, S. M. (2019). Greasing the wheels of change: bribery, institutions, and new product introductions in emerging markets. Journal of Management, 0149206317736588.

Krammer, S. (2021). Research performance in Business and Management: The impact of team size and diversity. In Academy of Management Proceedings (Vol. 2021, No. 1, p. 10981). Briarcliff Manor, NY 10510: Academy of Management. 
Laursen, K. and Foss, N.J. (2003): New Human Resource Management Practices, Complementarities and the Impact on Innovation Performance. Cambridge Journal of Economics 2003, 27, pp. 243-263

Lau, C. M., \& Ngo, H. Y. (2004). The HR system, organizational culture, and product innovation. International business review, 13(6), 685-703.

Lederman, D. (2010). An international multilevel analysis of product innovation. Journal of International Business Studies, 41(4), 606-619.

Lee, H. and Kelley, D. (2008): Building dynamic capabilities for innovation: an exploratory study of key management practices. $R \& D$ Management 38, 2, 2008, pp. 115-168.

Loon, M., Otaye-Ebede, L., \& Stewart, J. (2020). Thriving in the new normal: The HR microfoundations of capabilities for business model innovation. An integrated literature review. Journal of Management Studies, 57(3), 698-726.

Lopez-Berzosa, D., \& Gawer, A. (2014). Innovation policy within private collectives: Evidence on $3 \mathrm{GPP}^{\prime} \mathrm{s}$ regulation mechanisms to facilitate collective innovation. Technovation, 34(12), 734-745.

Lu, J., Liu, X., Wright, M., \& Filatotchev, I. (2014). International experience and FDI location choices of Chinese firms: The moderating effects of home country government support and host country institutions. Journal of International Business Studies, 45(4), 428-449.

Maksimov, V., Wang, S. L., \& Luo, Y. (2017). Institutional imprinting, entrepreneurial agency, and private firm innovation in transition economies. Journal of World Business, 52(6), 854865.

Meyer, K. E., Estrin, S., Bhaumik, S. K., \& Peng, M. W. (2009). Institutions, resources, and entry strategies in emerging economies. Strategic management journal, 30(1), 61-80.

Mumford, M.D. (2000): Managing Creative People: Strategies and Tactics for Innovation. Human Resource Management Review, Vol. 10, No. 3, pp. 313-351

Nocco, A., Ottaviano, G. I., \& Salto, M. (2019). Geography, competition, and optimal multilateral trade policy. Journal of International Economics, 120, 145-161.

Nuruzzaman, N., Gaur, A. S., \& Sambharya, R. B. (2019). A microfoundations approach to studying innovation in multinational subsidiaries. Global Strategy Journal, 9(1), 92-116.

O'Connor, G. C., and C. M. McDermott. 2004. The human side of radical innovation. Journal of Engineering and Technology Management 21(1-2): 11-30.

Park, O., Bae, J., \& Hong, W. (2019). High-commitment HRM system, HR capability, and ambidextrous technological innovation. The International Journal of Human Resource Management, 30(9), 1526-1548.

Pichault, F., and McKeown, T. (2019). Autonomy at work in the gig economy: analysing work status, work content and working conditions of independent professionals. New Technology, Work and Employment, 34(1), 59-72.

Power, D., and Sohal, A. S. (2000). Human resource management strategies and practices in justin-time environments: Australian case study evidence. Technovation, 20(7), 373-387.

Purcell, J., \& Hutchinson, S. (2007). Front-line managers as agents in the HRM-performance causal chain: theory, analysis and evidence. Human Resource management journal, 17(1), 3-20.

Pudelko, M., \& Harzing, A. W. (2007). Country-of-origin, localization, or dominance effect? An empirical investigation of HRM practices in foreign subsidiaries. Human Resource Management, 46(4), 535-559.

Raymond, L. and St-Pierre, J. (2010) R\&D as a determinant of innovation in manufacturing SMEs: an attempt at empirical clarification. Technovation, 30: 48-56. 
Raudenbush, S. W., \& Bryk, A. S. (2002). Hierarchical linear models: Applications and data analysis methods (Vol. 1). sage.

Rodrigo-Sanbartolomé, F. A. (2020). Comparing the legal treatment of employee-created intellectual and industrial property from a labour law perspective. International Journal of Intellectual Property Management, 10(1), 92-97.

Santiago, F. (2013): How Human Resource Management Practices Contribute to Learning for Pharmaceutical Innovation in Mexico: Drawing from Internal and External Sources of Knowledge. Latin American Business Review, 14:3-4, pp. 227-250

Schot, J., \& Steinmueller, W. E. (2018). Three frames for innovation policy: R\&D, systems of innovation and transformative change. Research Policy, 47(9), 1554-1567.

Schumpeter, J.A. (1934): The Theory of Economic Development. Harvard University Press, Cambridge, MA

Sears, G.J. and Baba, V.V. (2011): Toward a Multistage, Multilevel Theory of Innovation. Canadian Journal of Administrative Sciences 28(4), pp. 357-372.

Searle, R. H., \& Ball, K. S. (2003). Supporting innovation through HR policy: Evidence from the UK. Creativity and Innovation Management, 12(1), 50-62.

Seeck, H., \& Diehl, M. R. (2017). A literature review on HRM and innovation-taking stock and future directions. The International Journal of Human Resource Management, 28(6), 913944.

Shalley, C.E , Zhou, J. and Oldham, G.R. (2004): The effects of personal and contextual characteristics on creativity: Where should we go from here? Journal of Management 2004 30(6), pp. 933-958

Shipton, H., Fay, D., West, M., Patterson, M. and Birdi, K. (2005): Managing People to Promote Innovation. Creativity and Innovation Management, Vol. 14, No. 2, pp. 118-128

Shipton, H., West, M. A., Dawson, J., Birdi, K., \& Patterson, M. (2006). HRM as a predictor of innovation. Human resource management journal, 16(1), 3-27.

Shipton, H., West, M.A., Dawson, J., Birdi, K. and Patterson, M. (2006): HRM as a predictor of innovation. Human Resource Management Journal, Vol. 16, No. 1, 2006, pp. 3-27.

Snijders, T. A., \& Bosker, R. J. (2011). Multilevel analysis: An introduction to basic and advanced multilevel modeling. Sage.

Sparrow, P., Shipton, H., Budhwar, P., \& Brown, A. (Eds.). (2016). Human resource management, innovation and performance. Springer.

Teece, D.J., Pisano, G. and Shuen, A. (1997): Dynamic Capabilities and Strategic Management. Strategic Management Journal, Vol. 18, No. 7, pp. 509-533.

Towse, R. (2001). Creativity, Incentive and Reward. Books.

Traiberman, S. (2019). Occupations and import competition: Evidence from Denmark. American Economic Review, 109(12), 4260-4301.

Van Hoorn, A. (2014). Individualism and the cultural roots of management practices. Journal of Economic Behavior \& Organization, 99, 53-68.

Wakelin, K. (1998): Innovation and export behavior at the firm level. Research Policy 26 (1998), pp. 829-841

Wang, A.-C. and Cheng, B.-S. (2010): When does benevolent leadership lead to creativity? The moderating role of creative role identity and job autonomy. Journal of Organizational Behavior, Vol. 31, No. 1 (January 2010), pp. 106-121

Yasar, M., Paul, C. J. M., \& Ward, M. R. (2011). Property rights institutions and firm performance: a cross-country analysis. World Development, 39(4), 648-661. 
Zhou, Y., Hong, Y. and Liu, J. (2013): Internal Commitment or External Collabouration? The Impact of Human Resource Management Systems on Firm Innovation and Performance. Human Resource Management, March-April 2013, Vol. 52, No. 2, pp. 263-288

Zoghi, C., Mohr, R.D. and Meyer, P.B. (2010): Workplace organization and innovation. The Canadian Journal of Economics, Vol. 43, No. 2, pp. 622-639 
Table 1. Means, standard deviations and correlations of variables employed

\begin{tabular}{|c|c|c|c|c|c|c|c|c|c|c|c|c|c|c|}
\hline & & & Std. & & & & & & & & & & & \\
\hline No & Variable & Mean & Dev. & 1 & 2 & 3 & 4 & 5 & 6 & 7 & 8 & 9 & 10 & 11 \\
\hline$\overline{11}$ & "RD & 0.40 & 0.49 & 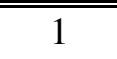 & & & & & & & & & & \\
\hline 2 & ln_size & 5.02 & 0.88 & $0.16^{*}$ & 1 & & & & & & & & & \\
\hline 3 & ln_age & 3.14 & 0.96 & 0.05 & $0.25^{*}$ & 1 & & & & & & & & \\
\hline 4 & multiest & 0.30 & 0.46 & 0.06 & $0.11 *$ & 0.05 & 1 & & & & & & & \\
\hline 5 & foreign_own & 0.10 & 0.30 & 0.04 & $0.07 *$ & -0.03 & $0.13 *$ & 1 & & & & & & \\
\hline 6 & state_own & 0.09 & 0.29 & -0.03 & $0.13^{*}$ & $0.20 *$ & $-0.07 *$ & $-0.08 *$ & 1 & & & & & \\
\hline 7 & competition & 2.47 & 0.70 & $0.07 *$ & -0.03 & -0.04 & -0.01 & -0.05 & -0.04 & 1 & & & & \\
\hline 8 & JA & 0.02 & 1.19 & $0.08 *$ & 0.01 & -0.05 & 0.05 & 0.02 & -0.03 & -0.02 & 1 & & & \\
\hline 9 & PBP & 0.01 & 1.32 & $0.11 *$ & -0.03 & $-0.12 *$ & 0.04 & $-0.08 *$ & -0.05 & 0.03 & 0.02 & 1 & & \\
\hline 10 & Labour_regul & 0.62 & 0.15 & 0.03 & $0.11 *$ & -0.02 & $-0.20 *$ & -0.06 & -0.01 & 0.03 & 0.04 & -0.06 & 1 & \\
\hline 11 & Import_compet & 0.73 & 0.44 & $0.15^{*}$ & $0.07 *$ & 0.023 & 0.01 & 0.05 & 0.02 & $0.15^{*}$ & $0.10^{*}$ & -0.01 & -0.03 & 1 \\
\hline
\end{tabular}

Note: * denotes statistical significance at $5 \%$ level or better. 
Table 2. Principal component analysis (PCA) rotated using orthogonal varimax method

\begin{tabular}{lcc}
\hline \hline Variables & $\begin{array}{c}\text { Performance-based pay } \\
(\boldsymbol{P B P})\end{array}$ & Job autonomy \\
\hline taskallocation & -0.005 & $\mathbf{J A})$ \\
pacework & -0.008 & $\mathbf{0 . 6 9 3}$ \\
perfcolfreq & -0.060 & -0.090 \\
perfshowfreq & 0.055 & 0.080 \\
prodreward & $\mathbf{0 . 7 0 5}$ & -0.014 \\
staffreward & $\mathbf{0 . 7 0 0}$ & 0.001 \\
underperf & 0.062 & 0.103 \\
\hline Eigen value & 1.780 & 1.441 \\
\hline \hline
\end{tabular}

Note: Highest factor loadings are in bold. 
Table 3. Variables employed in the Principal Component Analysis for HRM practices

\begin{tabular}{|c|c|c|}
\hline Variables & Details & Range \\
\hline taskallocation & $\begin{array}{l}\text { Allocation of tasks determined by: } \\
1 \text { - Only factory managers } \\
2 \text { - Mostly factory managers } \\
3 \text { - Factory managers and workers equally } \\
4 \text { - Mostly workers } \\
5 \text { - Only workers }\end{array}$ & $1-5$ \\
\hline pacework & $\begin{array}{l}\text { Pace of work determined by: } \\
1 \text { - Only factory managers } \\
2 \text { - Mostly factory managers } \\
3 \text { - Factory managers and workers equally } \\
4 \text { - Mostly workers } \\
5 \text { - Only workers }\end{array}$ & $1-5$ \\
\hline perfcolfreq & $\begin{array}{l}\text { Frequency of performance indicator collection: } \\
1 \text { - Yearly } \\
2 \text { - Quarterly } \\
3 \text { - Monthly } \\
4-\text { Weekly } \\
5 \text { - Daily } \\
6 \text { - Hourly }\end{array}$ & $1-6$ \\
\hline perfshowfreq & $\begin{array}{l}\text { Frequency of showing performance indicators to workers: } \\
0 \text { - Never } \\
1 \text { - Annually } \\
\text { 2- Half-annually } \\
3 \text { - Quarterly } \\
4 \text { - Monthly } \\
\text { 5- Weekly } \\
6 \text { - Daily } \\
7 \text { - Hourly }\end{array}$ & $0-7$ \\
\hline prodreward & Reward for achievement of production target? & $0-1$ \\
\hline staffreward & Is all staff is rewarded? & $0-1$ \\
\hline underperf & $\begin{array}{l}\text { How underperformers are dealt with: } \\
1 \text { - Rarely or never moved from their positions } \\
2 \text { - Usually stay in position for at least a year before action is } \\
\text { taken } \\
3 \text { - Rapidly helped or re-trained, dismissed if necessary }\end{array}$ & $1-3$ \\
\hline
\end{tabular}

Note: All these items come from questions in the MOI Survey. 
Table 4. HR policies, the external environment, and firm innovative performance

\begin{tabular}{|c|c|c|c|c|c|c|c|c|c|}
\hline Variables & Model 1 & Model 2 & Model 3 & Model 4 & Model 5 & Model 6 & Model 7 & Model 8 & Model 9 \\
\hline ln_size & $\begin{array}{c}0.230 * * * \\
{[0.042]}\end{array}$ & $\begin{array}{c}0.227 * * * \\
{[0.042]}\end{array}$ & $\begin{array}{c}0.226 * * * \\
{[0.042]}\end{array}$ & $\begin{array}{c}0.222 * * * \\
{[0.042]}\end{array}$ & $\begin{array}{c}0.230 * * * \\
{[0.051]}\end{array}$ & $\begin{array}{c}0.221^{* * *} \\
{[0.051]}\end{array}$ & $\begin{array}{c}0.203^{* * * *} \\
{[0.042]}\end{array}$ & $\begin{array}{c}0.209 * * * \\
{[0.042]}\end{array}$ & $\begin{array}{c}0.218 * * * \\
{[0.052]}\end{array}$ \\
\hline ln_age & $\begin{array}{c}0.02 \\
{[0.040]}\end{array}$ & $\begin{array}{c}0.033 \\
{[0.040]}\end{array}$ & $\begin{array}{c}0.022 \\
{[0.040]}\end{array}$ & $\begin{array}{c}0.035 \\
{[0.040]}\end{array}$ & $\begin{array}{c}0.024 \\
{[0.048]}\end{array}$ & $\begin{array}{c}0.01 \\
{[0.047]}\end{array}$ & $\begin{array}{c}0.053 \\
{[0.039]}\end{array}$ & $\begin{array}{c}0.04 \\
{[0.039]}\end{array}$ & $\begin{array}{c}0.039 \\
{[0.047]}\end{array}$ \\
\hline multiest & $\begin{array}{c}0.097 \\
{[0.088]}\end{array}$ & $\begin{array}{c}0.087 \\
{[0.088]}\end{array}$ & $\begin{array}{c}0.096 \\
{[0.088]}\end{array}$ & $\begin{array}{c}0.087 \\
{[0.088]}\end{array}$ & $\begin{array}{c}0.024 \\
{[0.106]}\end{array}$ & $\begin{array}{c}0.049 \\
{[0.106]}\end{array}$ & $\begin{array}{c}0.200 * * \\
{[0.081]}\end{array}$ & $\begin{array}{c}0.199 * * \\
{[0.081]}\end{array}$ & $\begin{array}{c}0.087 \\
{[0.097]}\end{array}$ \\
\hline foreign_own & $\begin{array}{c}-0.028 \\
{[0.109]}\end{array}$ & $\begin{array}{c}0.001 \\
{[0.110]}\end{array}$ & $\begin{array}{c}-0.033 \\
{[0.110]}\end{array}$ & $\begin{array}{c}-0.005 \\
{[0.110]}\end{array}$ & $\begin{array}{c}0.163 \\
{[0.146]}\end{array}$ & $\begin{array}{c}0.127 \\
{[0.145]}\end{array}$ & $\begin{array}{c}-0.001 \\
{[0.110]}\end{array}$ & $\begin{array}{c}-0.045 \\
{[0.110]}\end{array}$ & $\begin{array}{c}0.153 \\
{[0.146]}\end{array}$ \\
\hline state_own & $\begin{array}{c}-0.095 \\
{[0.143]}\end{array}$ & $\begin{array}{c}-0.086 \\
{[0.143]}\end{array}$ & $\begin{array}{c}-0.095 \\
{[0.143]}\end{array}$ & $\begin{array}{c}-0.086 \\
{[0.143]}\end{array}$ & $\begin{array}{c}-0.194 \\
{[0.159]}\end{array}$ & $\begin{array}{c}-0.204 \\
{[0.158]}\end{array}$ & $\begin{array}{c}-0.151 \\
{[0.139]}\end{array}$ & $\begin{array}{c}-0.161 \\
{[0.138]}\end{array}$ & $\begin{array}{c}-0.218 \\
{[0.156]}\end{array}$ \\
\hline competition & $\begin{array}{c}0.130 * * \\
{[0.052]}\end{array}$ & $\begin{array}{c}0.125 * * \\
{[0.052]}\end{array}$ & $\begin{array}{c}0.137 * * * \\
{[0.052]}\end{array}$ & $\begin{array}{c}0.132 * * \\
{[0.052]}\end{array}$ & $\begin{array}{c}0.148 * * \\
{[0.064]}\end{array}$ & $\begin{array}{c}0.152 * * \\
{[0.064]}\end{array}$ & $\begin{array}{c}0.130 * * \\
{[0.052]}\end{array}$ & $\begin{array}{c}0.136^{* * * *} \\
{[0.052]}\end{array}$ & $\begin{array}{c}0.147 * * \\
{[0.065]}\end{array}$ \\
\hline $\begin{array}{l}\text { H1: Performance-based pay } \\
\text { (PBP) }\end{array}$ & & $\begin{array}{c}0.079 * * * \\
{[0.028]}\end{array}$ & & $\begin{array}{c}0.077 * * * \\
{[0.028]}\end{array}$ & $\begin{array}{c}0.228 * * * \\
{[0.081]}\end{array}$ & & $\begin{array}{l}0.257+ \\
{[0.146]}\end{array}$ & & $\begin{array}{l}0.349+ \\
{[0.191]}\end{array}$ \\
\hline $\begin{array}{l}\text { H2: Job Autonomy } \\
\text { (JA) }\end{array}$ & & & $\begin{array}{c}0.078 * * \\
{[0.031]}\end{array}$ & $\begin{array}{c}0.076 * * \\
{[0.031]}\end{array}$ & & $\begin{array}{c}-0.069 \\
{[0.076]}\end{array}$ & & $\begin{array}{c}-0.131 \\
{[0.139]}\end{array}$ & $\begin{array}{r}-0.327+ \\
{[0.174]}\end{array}$ \\
\hline Import_compet & & & & & $\begin{array}{c}0.398 * * * \\
{[0.102]}\end{array}$ & $\begin{array}{c}0.379 * * * \\
{[0.102]}\end{array}$ & & & $\begin{array}{c}0.406^{* * *} \\
{[0.104]}\end{array}$ \\
\hline H3a: PBP * Import_compet & & & & & $\begin{array}{r}-0.134+ \\
{[0.077]}\end{array}$ & & & & $\begin{array}{r}-0.131+ \\
{[0.076]}\end{array}$ \\
\hline H3b: JA * Import_compet & & & & & & $\begin{array}{l}0.176 * * \\
{[0.086]}\end{array}$ & & & $\begin{array}{l}0.161+ \\
{[0.088]}\end{array}$ \\
\hline Labour_regul & & & & & & & $\begin{array}{c}0.590 * * \\
{[0.263]}\end{array}$ & $\begin{array}{c}0.425 \\
{[0.259]}\end{array}$ & $\begin{array}{c}0.245 \\
{[0.304]}\end{array}$ \\
\hline
\end{tabular}


H4a: PBP * Labour_regul

$\begin{array}{ccc}\mathbf{- 0 . 2 8 2} & & -0.200 \\ {[\mathbf{0 . 2 2 9}]} & & {[0.266]} \\ & \mathbf{0 . 4 3 9} * * & 0.426+ \\ & {[\mathbf{0 . 2 1 7}]} & {[0.247]}\end{array}$

H4b: JA * Labour_regul

[0.217] [0.247]

\begin{tabular}{lccccccccc} 
constant & $-2.866 * * *$ & $-2.893 * * *$ & $-2.842^{* * *}$ & $-2.870^{* * *}$ & $-2.999 * * *$ & $-2.817 * * *$ & $-2.721 * * *$ & $-2.626 * * *$ & $-2.868 * * *$ \\
& {$[0.351]$} & {$[0.351]$} & {$[0.351]$} & {$[0.352]$} & {$[0.429]$} & {$[0.426]$} & {$[0.324]$} & {$[0.322]$} & {$[0.401]$} \\
\hline Industry FE & Yes & Yes & Yes & Yes & Yes & Yes & Yes & Yes & Yes \\
Country FE & Yes & Yes & Yes & Yes & Yes & Yes & No & No & No \\
\hline \hline $\mathrm{N}$ & 1,266 & 1,266 & 1,266 & 1,266 & 944 & 944 & 1,266 & 1,266 & 944 \\
Log Likelihood & -824.414 & -820.511 & -821.176 & -817.411 & -596.015 & -599.651 & -820.871 & -821.293 & -590.955 \\
LR Chi Square & 78.2 & 86.005 & 84.676 & 92.205 & 78.939 & 71.668 & 85.285 & 84.44 & 89.059 \\
AIC & 1666.827 & 1661.023 & 1662.351 & 1656.822 & 1216.03 & 1223.301 & 1663.742 & 1664.587 & 1213.91 \\
BIC & 1713.12 & 1712.459 & 1713.787 & 1713.402 & 1274.232 & 1281.503 & 1720.322 & 1721.167 & 1291.512 \\
\hline \hline
\end{tabular}

Notes: Robust standard errors are reported in parentheses. $* * * \mathrm{p}<0.01, * * \mathrm{p}<0.05,+\mathrm{p}<10$. 
APPENDIX A.

Table A1. Breakdown of the data by industry/sector

\begin{tabular}{l|c|cc}
\hline \hline Industry & ISIC & Obs. & \% \\
& Code & & \\
\hline \hline Food products and beverages & 15 & 187 & 14.77 \\
Tobacco products & 16 & 4 & 0.32 \\
Textiles & 17 & 96 & 7.58 \\
Wearing apparel & 18 & 82 & 6.48 \\
Tanning and dressing of leather & 19 & 20 & 1.58 \\
Wood and wood cork products & 20 & 22 & 1.74 \\
Paper and paper products & 21 & 29 & 2.29 \\
Publishing, printing and recorded media & 22 & 70 & 5.53 \\
Coke, refined petroleum products and nuclear fuel & 23 & 5 & 0.39 \\
Chemicals and chemical products & 24 & 78 & 6.16 \\
Rubber and plastics products & 25 & 63 & 4.98 \\
Other non-metallic mineral products & 26 & 77 & 6.08 \\
Basic metals & 27 & 33 & 2.61 \\
Fabricated metal products & 28 & 121 & 9.56 \\
Machinery and equipment & 29 & 129 & 10.19 \\
Office, accounting and computing machinery & 30 & 5 & 0.39 \\
Electrical machinery and apparatus & 31 & 74 & 5.85 \\
Radio, television and communication equipment & 32 & 17 & 1.34 \\
Medical, precision and optical instruments & 33 & 37 & 2.92 \\
Motor vehicles, trailers and semi-trailers & 34 & 40 & 3.16 \\
Other transport equipment & 35 & 20 & 1.58 \\
Furniture & 36 & 47 & 3.71 \\
Recycling & 37 & 10 & 0.79 \\
\hline Total & - & 1,266 & 100.0 \\
\hline \hline
\end{tabular}

Note: ISIC codes based on United Nations ISIC Rev. 3.1 
Table A2. Breakdown of the data by country

\begin{tabular}{l|cc}
\hline \hline Countries & Obs. & \% \\
\hline \hline Belarus & 64 & 5.06 \\
Bulgaria & 98 & 7.74 \\
Germany & 172 & 13.59 \\
India & 178 & 14.06 \\
Kazakhstan & 98 & 7.74 \\
Lithuania & 73 & 5.77 \\
Poland & 54 & 4.27 \\
Romania & 90 & 7.11 \\
Russia & 153 & 12.09 \\
Serbia & 92 & 7.27 \\
Ukraine & 106 & 8.37 \\
Uzbekistan & 88 & 6.95 \\
\hline Total & 1,266 & 100 \\
\hline \hline
\end{tabular}


Table 3. Robustness checks: Multi-level mixed estimations

\begin{tabular}{|c|c|c|c|c|c|c|c|c|}
\hline Variables & Model 10 & Model 11 & Model 12 & Model 13 & Model 14 & Model 15 & Model 16 & Model 17 \\
\hline \multirow[t]{2}{*}{ ln_size } & $0.221 * * *$ & $0.216 * * *$ & $0.218 * * *$ & $0.225 * * *$ & $0.215^{* * *}$ & $0.206^{* * *}$ & $0.219 * * *$ & $0.219 * * *$ \\
\hline & {$[0.043]$} & {$[0.044]$} & {$[0.043]$} & {$[0.053]$} & {$[0.053]$} & {$[0.043]$} & {$[0.043]$} & {$[0.053]$} \\
\hline \multirow[t]{2}{*}{ ln_age } & 0.013 & 0.024 & 0.018 & 0.031 & 0.021 & 0.03 & 0.015 & 0.044 \\
\hline & [0.042] & [0.042] & [0.042] & [0.050] & [0.049] & [0.042] & [0.042] & {$[0.050]$} \\
\hline \multirow[t]{2}{*}{ multiest } & 0.145 & 0.145 & 0.142 & 0.061 & 0.071 & $0.177+$ & 0.137 & 0.087 \\
\hline & {$[0.093]$} & {$[0.094]$} & {$[0.093]$} & {$[0.112]$} & {$[0.111]$} & {$[0.092]$} & {$[0.093]$} & {$[0.109]$} \\
\hline \multirow[t]{2}{*}{ foreign_own } & -0.029 & -0.003 & -0.033 & 0.191 & 0.161 & -0.008 & -0.03 & 0.185 \\
\hline & {$[0.114]$} & {$[0.115]$} & {$[0.114]$} & {$[0.152]$} & {$[0.151]$} & {$[0.116]$} & {$[0.115]$} & {$[0.153]$} \\
\hline \multirow[t]{2}{*}{ state_own } & -0.07 & -0.057 & -0.074 & -0.149 & -0.167 & -0.081 & -0.063 & -0.175 \\
\hline & [0.149] & {$[0.150]$} & [0.148] & [0.168] & [0.166] & [0.149] & [0.148] & {$[0.166]$} \\
\hline \multirow[t]{2}{*}{ competition } & $0.094+$ & 0.084 & $0.102+$ & 0.106 & $0.113+$ & 0.088 & $0.104+$ & 0.107 \\
\hline & {$[0.053]$} & {$[0.053]$} & {$[0.054]$} & {$[0.065]$} & {$[0.065]$} & {$[0.054]$} & {$[0.054]$} & {$[0.066]$} \\
\hline \multirow[t]{2}{*}{ H1: PBP } & & $0.093 * * *$ & & $0.244 * * *$ & & $0.265+$ & & $0.373+$ \\
\hline & & {$[0.029]$} & & {$[0.084]$} & & {$[0.149]$} & & {$[0.194]$} \\
\hline \multirow[t]{2}{*}{ H2: JA } & & & $0.068 * *$ & & 0.087 & & -0.138 & $0.331+$ \\
\hline & & & {$[0.031]$} & & {$[0.077]$} & & {$[0.148]$} & {$[0.175]$} \\
\hline \multirow[t]{2}{*}{ Import_compet } & & & & $0.399 * * *$ & $0.383 * * *$ & & & $0.406 * * *$ \\
\hline & & & & {$[0.104]$} & {$[0.103]$} & & & {$[0.106]$} \\
\hline \multirow{3}{*}{$\begin{array}{l}\text { H3a: PBP * } \\
\text { Import_compet }\end{array}$} & & & & & & & & \\
\hline & & & & $-0.140+$ & & & & -0.136 \\
\hline & & & & {$[0.079]$} & & & & {$[0.093]$} \\
\hline \multirow{3}{*}{$\begin{array}{l}\text { H3b: JA * } \\
\text { Import_compet }\end{array}$} & & & & & & & & \\
\hline & & & & & $0.192 * *$ & & & $0.178 * *$ \\
\hline & & & & & {$[0.088]$} & & & {$[0.089]$} \\
\hline \multirow[t]{2}{*}{ Labour_regul } & & & & & & 0.483 & 0.517 & 0.013 \\
\hline & & & & & & {$[0.521]$} & [0.423] & {$[0.562]$} \\
\hline \multirow{3}{*}{$\begin{array}{l}\text { H4a: PBP * } \\
\text { Labour_regul }\end{array}$} & & & & & & & & \\
\hline & & & & & & -0.276 & & -0.216 \\
\hline & & & & & & {$[0.233]$} & & {$[0.269]$} \\
\hline \multirow{2}{*}{$\begin{array}{l}\text { H4b: JA * } \\
\text { Labour_regul }\end{array}$} & & & & & & & + & 0400 \\
\hline & & & & & & & [0.181] & {$[0.249]$} \\
\hline \multirow[t]{2}{*}{ constant } & $-2.768 * * *$ & $-2.774 * * *$ & $-2.762 * * *$ & $-3.064 * * *$ & $-2.867 * * *$ & $-2.482 * * *$ & -2.427 & $-2.637 * * *$ \\
\hline & {$[0.452]$} & {$[0.465]$} & {$[0.446]$} & {$[0.544]$} & {$[0.534]$} & {$[0.436]$} & [51.259] & {$[0.504]$} \\
\hline Firm RE & Yes & Yes & Yes & Yes & Yes & Yes & Yes & Yes \\
\hline Country FE & Yes & Yes & Yes & Yes & Yes & No & No & Yes \\
\hline Industry FE & Yes & Yes & Yes & Yes & Yes & Yes & Yes & Yes \\
\hline $\mathrm{N}$ & 1,266 & 1,266 & 1,266 & 944 & 944 & 1,266 & 1,266 & 944 \\
\hline Log Likelihood & -818.946 & -813.766 & -816.521 & -591.159 & -595.568 & -814.036 & -816.499 & -586.601 \\
\hline AIC & 1657.891 & 1649.531 & 1655.043 & 1208.318 & 1217.137 & 1652.073 & 1658.998 & 1207.202 \\
\hline $\mathrm{BIC}$ & 1709.32 & 1706.102 & 1711.614 & 1271.355 & 1280.175 & 1713.787 & 1725.855 & 1289.636 \\
\hline
\end{tabular}


Notes: Robust standard errors are reported in parentheses. $* * * \mathrm{p}<0.01, * * \mathrm{p}<0.05,+\mathrm{p}<10$. 